\title{
Environmental Availability of Trace Metals (Mercury, Chromium and Nickel) in Soils from the Abandoned Mine Area of Merník (Eastern Slovakia)
}

\author{
Edgar Hiller ${ }^{1 *}$, L'ubomír Jurkovičc, Juraj Majzlan², Tatsiana Kulikova ${ }^{1}$, Tomáš Faragó ${ }^{1}$ \\ ${ }^{1}$ Department of Geochemistry, Faculty of Natural Sciences, Comenius University in Bratislava, \\ Ilkovičova 6, 84215 Bratislava, Slovak Republic \\ ${ }^{2}$ Institute of Geosciences, Burgweg 11, Friedrich-Schiller University, 07749 Jena, Germany
}

Received: 3 December 2020

Accepted: 26 February 2021

\begin{abstract}
The former mercury ore deposit of Merník in Eastern Slovakia was selected for the investigation of the environmental availability of mercury $(\mathrm{Hg})$, chromium $(\mathrm{Cr})$ and nickel $(\mathrm{Ni})$ in mine soils. Singlestep extractions with four chemical agents (deionised water, ethylenediaminetetraacetic (EDTA), acetic $\left(\mathrm{CH}_{3} \mathrm{COOH}\right)$ and hydrochloric $(\mathrm{HCl})$ acid solutions) and chemical analysis of the common nettle (Urtica dioica) were used to determine the availability of the three metals. Regardless of the type of extraction, the soluble ratios of metals in mine soils increased in the order of $\mathrm{Hg} \leq \mathrm{Cr}<\mathrm{Ni}$, while the extraction efficiency of individual reagents followed generally the order of $\mathrm{HCl}>\mathrm{CH}_{3} \mathrm{COOH} \approx \mathrm{EDTA}>>\mathrm{H}_{2} \mathrm{O}$. The total or extractable metal concentrations in soil did not correlate with their concentrations in aerial parts of the common nettle, however, its ability to accumulate these trace metals in roots and aerial parts copied the results of extraction tests, i.e. $\mathrm{Hg} \leq \mathrm{Cr}<\mathrm{Ni}$. Only correlations existed between the $\mathrm{H}_{2} \mathrm{O}$ extractable metal concentrations and the plant root concentrations. Bioconcentration factor (BCF) and translocation factor (TF) were considerably lower than 1.0, while BCF values for Ni were sensitive to soil $\mathrm{pH}$, with higher values in more acid soils. The plant availability of $\mathrm{Hg}$ and $\mathrm{Cr}$ was by one order of magnitude lower than that of $\mathrm{Ni}$, indicating that the former mine area poses no serious environmental and health risks, despite high metal concentrations in soil. Higher plant availability of Ni compared to $\mathrm{Hg}$ and $\mathrm{Cr}$ was likely due to high $\mathrm{Ni}$ solubility in $\mathrm{CH}_{3} \mathrm{COOH}$ and EDTA solutions $(10.3 \pm 5.51 \%$ and $9.39 \pm 4.50 \%$ of the total soil concentration, respectively), which release the metals present in exchangeable form, carbonate bound and complexed with soil organic matter. Low Hg availability could
\end{abstract}

*e-mail: edgar.hiller@uniba.sk 
be explained by its binding to stable cinnabar(metacinnabar) as indicated by extended X-ray absorption fine structure (EXAFS) and $\mu$-X-ray fluorescence ( $\mu$-XRF).

Keywords: mercury, mobility, soil, plants, trace metals

\section{Introduction}

Mercury, $\mathrm{Cr}$ and $\mathrm{Ni}$ are trace metals with average concentrations in the upper continental earth's crust of $0.06 \mathrm{mg} / \mathrm{kg}, 53 \mathrm{mg} / \mathrm{kg}$ and $26.3 \mathrm{mg} / \mathrm{kg}$, respectively [1-2]. Increased $\mathrm{Hg}$ contents in soils are associated with anthropogenic emissions, mainly from mining, waste management, electrical engineering, the use of $\mathrm{Hg}$ in the extraction of precious metals and chlor-alkali plants [3-4]. This metal is characterized by significant toxicity to all living organisms, including humans [5-6]. Similarly, high concentrations of $\mathrm{Cr}$ and $\mathrm{Ni}$ are commonly detected in mine soils, soils from nickel smelters and non-ferrous metal processing complexes [7-11]. Typical of geochemically anomalous concentrations of $\mathrm{Cr}$ and $\mathrm{Ni}$ are also the so-called serpentine soils developed on ultrabasic rocks [1215]. In this case, it is not an anthropogenic soil contamination but geogenic derived from naturally high contents of $\mathrm{Cr}, \mathrm{Ni}$ and geochemically related elements in the underlying rock substrate [16-18].

Mobility of $\mathrm{Hg}, \mathrm{Cr}$ and $\mathrm{Ni}$ in soils and their transfer from soil to plants is a complex function of several variables, such as geochemical fractionation of metals among soil components, physico-chemical and mineralogical characteristics of soil substrates and plant species [12-13, 19-26]. Total concentrations of trace metals are not of prime importance for assessing the ecological and health risks of contaminated soils. Instead, the readily soluble, exchangeable and weakly bound forms of these metals play the major role because they are available for migration into natural waters and plants [27-28]. Available forms of toxic trace metals are commonly determined by single-step extractions. For example, extraction procedures using water and acetic acid release highly available water-soluble metal fractions from the soil and exchangeable/bound to carbonates and hydroxides [22, 28]. Despite some success of in vitro single-step extractions with a specific reagent to predict plant uptake of trace metals, the most appropriate way to evaluate the actual availability of elements in plants is to measure their concentrations in the sampled plant species [29].

This study focused on the determination of the mobility, potential and actual bioavailability of $\mathrm{Hg}$, $\mathrm{Cr}$ and $\mathrm{Ni}$ in surface soils from the former cinnabar mine Merník (eastern Slovakia) through single-step extractions with four different chemical reagents and measuring trace metal concentrations in the common nettle (Urtica dioica). The reason for the selection of these three metals is the fact that they are the main anthropogenic $(\mathrm{Hg})$ and natural $(\mathrm{Cr}$ and $\mathrm{Ni})$ soil contaminants in this mine area [30]. It is a unique example of the differences in the availability of unusual geochemical association of elements due to the rock composition of the mine area: $\mathrm{Hg}$ derived from cinnabar mineralization in rhyodacites, and $\mathrm{Cr}$ and $\mathrm{Ni}$ bound to conglomerates consisting of pebbles of ultrabasic rocks. Therefore, the main objectives of this work were to evaluate (i) the soluble fractions of $\mathrm{Hg}, \mathrm{Cr}$ and $\mathrm{Ni}$ in soils by various reagents that mimic the release of trace metals in natural conditions, (ii) the transfer of metals from soil to the common nettle and (iii) possible influence of physico-chemical characteristics of soils on the mobility, bioavailability and transfer of trace metals into plants.

\section{Experimental}

\section{Brief Description of the Study Area}

The abandoned Hg deposit of Merník is situated approximately $1 \mathrm{~km}$ south of the village Merník in Eastern Slovakia, Vranov nad Toplou district, Prešov region (Fig. 1). Mercury ores, mostly cinnabar, were mined in the deposit from 1830 to 1939. In the deposit area, the $\mathrm{Hg}$ ores were processed by roasting in two rotary kilns and about $150 \mathrm{t}$ of pure $\mathrm{Hg}$ were produced during the whole period. The deposit is hosted by sediments of the Central Carpathian Paleogene, penetrated by stocks and dykes of rhyodacites (Upper Badenian - Lower Sarmatian). The mercury mineralization is dispersed in these rocks and forms veinlets and impregnations [31]. Conglomerates with pebbles of ultrabasic rocks (Lower Miocene), which are typically enriched in $\mathrm{Cr}$ and $\mathrm{Ni}$, are abundant in the area. The main ore mineral is cinnabar, accompanied by metacinnabar, pyrite and marcasite. The Quaternary consists of anthropogenic sediments, which are heaps and dumps (Holocene), as well as deluvial sediments, which are loams, sands and clayey gravels (Pleistocene-Holocene).

\section{Soil and Plant Collection}

Soil samples were collected at 10 sites and from the same points as the plant samples (Fig. 1). The soil samples were taken from a depth of $0-20 \mathrm{~cm}$ from the rhizosphere of each plant in clean polyethylene bags. Soil and plant sampling at each site was performed from an area of $1 \mathrm{~m}^{2}$, from which 3 soil and 3 plant subsamples were taken, which were then individually analysed for trace metal concentrations. For singlestep extraction procedures, the soils were also collected from a depth of $40-60 \mathrm{~cm}$ from the same sampling 


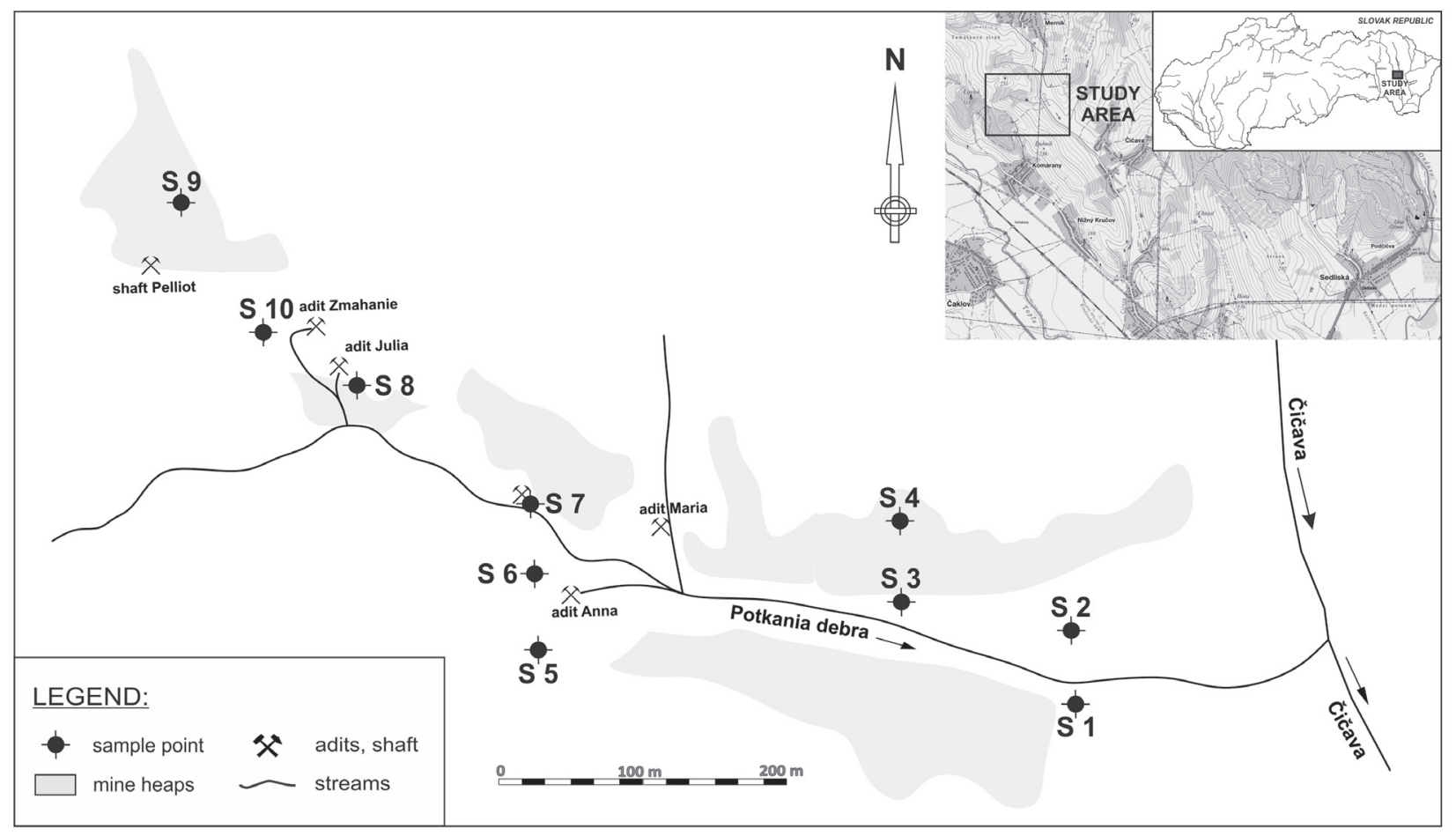

Fig. 1. Location of the study area (former mercury deposit Merník in Eastern Slovakia) and sampling points of soils and common nettle.

points. They were air-dried in the laboratory to constant weight, large aggregates were finely crushed and finally the soil samples were sieved to a size less than $2 \mathrm{~mm}$. During the vegetation period (July 2018), the common nettle (Urtica dioica), which is the predominant plant species in the mine area, was harvested. Fresh plants were removed from the soil by spade and divided into the aerial part (stems and leaves) and roots in the laboratory. The plant samples were rinsed thoroughly with tap water and then several times with deionised water to remove any external contamination. Plant parts were dried at room temperature to constant weight, then pulverized and sieved.

\section{Analytical Methods}

Mercury concentration in all soils, plants and extracts was determined by an advanced mercury analyser (AMA-254, Altec) in accredited laboratories of EL Ltd., Spišská Nová Ves, Slovakia. To measure the concentration of $\mathrm{Cr}$ and $\mathrm{Ni}$ in soils, $0.5 \mathrm{~g}$ of soil sample was digested in a microwave oven (model MDS $81 \mathrm{D}$, CEM Corporation) with a mixture of $9 \mathrm{~mL} \mathrm{HNO}_{3}$, $3 \mathrm{~mL} \mathrm{HCl}$ and $3 \mathrm{~mL} \mathrm{HF}$. The cooled, diluted and filtered extracts were analysed by inductively coupled plasma optical emission spectrometry (ICP-OES, Varian, Vista AX, CCD Simultaneous System). The concentration of $\mathrm{Cr}$ and $\mathrm{Ni}$ in the nettle was determined after digestion of dry and sieved samples $(0.5 \mathrm{~g})$ with $2 \mathrm{~mL} \mathrm{H}_{2} \mathrm{O}$, $2 \mathrm{~mL} \mathrm{H}_{2} \mathrm{O}_{2}$ and $4 \mathrm{~mL} \mathrm{HNO}_{3}$ in a microwave. The plant extracts were brought to $25 \mathrm{~mL}$ with deionised water and filtered through Whatman filter paper No. 42.
Standard reference materials for plant (ERM-CD281 - rye grass) and soil (ERM-CC141 - loam soil) were used to determine the accuracy and precision of the analytical methods. Laboratories declare the following detection limits for solid samples: $0.001 \mathrm{mg} / \mathrm{kg}$ for $\mathrm{Hg}$ and $0.1 \mathrm{mg} / \mathrm{kg}$ for $\mathrm{Cr}$ and $\mathrm{Ni}$. The soil $\mathrm{pH}$ and electrical conductivity (EC) were measured in soildeionised water suspensions in a 1:2.5 ratio (w/v) with glass electrode and conductivity meter, respectively. The total organic and inorganic carbon contents (TOC and IC, respectively) were determined by thermal decomposition of soils using a Ströhlein TOC-Analyser C-MAT 5500. The carbonate content was analysed using the pressure calcimeter method with $6 \mathrm{M} \mathrm{HCl}$ and expressed as a percentage of $\mathrm{CaCO}_{3}$. The standard pipette method was used for the determination of soil particle-size distribution (sand $<2.0 \mathrm{~mm}$, silt $<0.05 \mathrm{~mm}$ and clay $<0.002 \mathrm{~mm}$ ) [32].

\section{Extraction Protocols}

Four single-step extraction schemes using (i) deionised water $\left(\mathrm{H}_{2} \mathrm{O}\right)$, (ii) dilute ethylenediaminetetraacetic acid solution $(0.05 \quad \mathrm{M}$ EDTA), (iii) dilute acetic acid $\left(0.43 \mathrm{M} \mathrm{CH}_{3} \mathrm{COOH}\right)$ and (iv) dilute hydrochloric acid $(1.0 \mathrm{M} \mathrm{HCl})$ were adopted in this study. The proportions of elements soluble in $\mathrm{H}_{2} \mathrm{O}$, EDTA, $\mathrm{CH}_{3} \mathrm{COOH}$ and $\mathrm{HCl}$ are defined as easily mobilisable, potentially phytoavailable, mobilisable and reactive, respectively [27]. Extraction with $\mathrm{H}_{2} \mathrm{O}$ was performed with $5 \mathrm{~g}$ of soil and $50 \mathrm{~mL}$ of liquid phase for $16 \mathrm{~h}$ [33]. The potentially phytoavailable pool of trace 
metals was determined by extracting $5 \mathrm{~g}$ of soil with $50 \mathrm{~mL}$ of $0.05 \mathrm{M}$ EDTA solution (with $\mathrm{pH}=7$ ) for $2 \mathrm{~h}$ [34]. Extraction of soils with $0.43 \mathrm{M} \mathrm{CH}_{3} \mathrm{COOH}$ solution was performed in a soil:solution ratio of 1:40 $(\mathrm{w} / \mathrm{v})$ for $16 \mathrm{~h}$ [35] and the reactive pool was obtained by extraction of soil with $1.0 \mathrm{M} \mathrm{HCl}$ solution in a soil:solution ratio of $1: 10(\mathrm{w} / \mathrm{v})$ for $2 \mathrm{~h}$ [27]. All extractions were performed in a mechanical shaker at room temperature. The extracts were separated from the soil by centrifugation (6000 rpm for $10 \mathrm{~min})$ and then filtered through a $0.45 \mu \mathrm{m}$ filter. The supernatants were kept in a refrigerator at $4^{\circ} \mathrm{C}$ prior to the chemical analysis. Concentrations of $\mathrm{Hg}, \mathrm{Cr}$ and $\mathrm{Ni}$ in the soil extracts were analysed by the same analytical methods as used for soils and plants. The detection limits of the analytical methods used for $\mathrm{Hg}, \mathrm{Cr}$ and $\mathrm{Ni}$ in the solutions were $0.0001,0.002$ and $0.01 \mathrm{mg} / \mathrm{L}$, respectively.

\section{Micro X-ray Fluorescence ( $\mu$-XRF) and Extended $\mathrm{X}$-ray Absorption Fine Structure (EXAFS) Measurements}

Micro-XRF spectroscopy was done on polished sections prepared from selected soil samples. The $\mu$-XRF mapping of selected areas in these sections was carried out with a Bruker M4 TORNADO $\mu$-XRF spectrometer. The X-ray source was a Rh target with an accelerating voltage of $50 \mathrm{kV}$ and anode current of $600 \mu \mathrm{A}$. The analyses were performed with a beam of $20 \mu \mathrm{m}$ diameter, step of $17 \mu \mathrm{m}$, in energy-dispersive (EDS) mode, thus allowing simultaneous measurement of all elements between $\mathrm{Na}$ and $\mathrm{U}$. Sensitivity of the instrument is limited by spectra overlaps but it is very high for some elements (e.g., 20 ppm for $\mathrm{Cu}, 40$ ppm for $\mathrm{Fe}$, and 20 ppm for $\mathrm{Zn})$.

EXAFS spectra were measured using a SUL-X beam on a synchrotron KARA (Karlsruhe Research Accelerator, Eggenstein-Leopoldshafen, Germany). The spectra of the reference samples were obtained in the transmission mode and of the soil samples in the fluorescence mode at the edges $\mathrm{Hg} L_{1}(14.84 \mathrm{keV})$ and $L_{3}(12.28 \mathrm{keV})$.

\section{Data Analysis}

Bioconcentration factor (BCF) was used to evaluate the bioavailability of $\mathrm{Hg}, \mathrm{Cr}$ and $\mathrm{Ni}$ to the common nettle. The values of $\mathrm{BCF}$ were calculated as the ratio of the total metal concentration in the root $(\mathrm{mg} / \mathrm{kg})$ to its total concentration in the soil $(\mathrm{mg} / \mathrm{kg})$. The plant's ability to distribute metal from the roots to the aboveground parts was expressed using a translocation factor (TF), which is defined as the ratio of the total metal concentration in shoots $(\mathrm{mg} / \mathrm{kg})$ to its total concentration in roots $(\mathrm{mg} / \mathrm{kg})$. Three independent plant samples and respective soil samples at each site were taken into account and arithmetic mean and median were calculated. Nonparametric versions of statistical methods were used to identify the relationships between the two variables (Spearman correlation analysis) and differences in extraction efficiency among extractants for each metal and differences in plant uptake and in vitro single-step extractions among the three studied trace metals (Kruskal-Wallis test with Dunns post hoc test). Non-parametric versions were preferred because most variables did not have a normal distribution.

\section{Results}

\section{Soil Physico-Chemical and Mineralogical Properties and Total Metal Concentrations}

The $\mathrm{pH}$ values of surface soils varied considerably and were between 4.05 and 7.83. The $\mathrm{CaCO}_{3}$ content ranged from $2.75 \%$ to $19.5 \%$ and was higher in weakly alkaline soils (Table 1). The total organic carbon content in these mine soils was also very variable in the range from $0.95 \%$ to $3.77 \%$. The predominant grain categories were sand and silt with a clay content between $4.80-18.6 \%$, so according to the grain triangle, these surface soils fall into the group of silty loam. Subsurface soils had a similar $\mathrm{pH}, \mathrm{CaCO}_{3}$ content and grain size distribution as surface soils, only the TOC was significantly lower $(P<0.05)$.

The total concentrations of trace metals studied in soils are shown in Fig. 2. Soil concentrations of $\mathrm{Hg}$ varied by up to four orders of magnitude $(0.46 \mathrm{mg} / \mathrm{kg}$ up to $951 \mathrm{mg} / \mathrm{kg}$ ), highest in soils close to the tunnels and mine waste heaps. The median $\mathrm{Hg}$ concentration in these ten soils $(14.2 \mathrm{mg} / \mathrm{kg})$ significantly exceeded its global mean value $(1.1 \mathrm{mg} / \mathrm{kg}$; [3]) and was up to 170 times higher than the Slovak median $\mathrm{Hg}$ concentration in the A soil horizon, which is $0.08 \mathrm{mg} / \mathrm{kg}$ [36]. This comparison shows that historical anthropogenic perturbations in the study area (i.e. mining, grinding and smelting of $\mathrm{Hg}$ sulfides) are the main cause of soil contamination with $\mathrm{Hg}$. Mercury concentrations in subsurface soils were lower than those in surface soils (Fig. 2) $(9.33 \mathrm{mg} / \mathrm{kg}$ vs. $14.2 \mathrm{mg} / \mathrm{kg})$ but not significantly $(P>0.05)$. Concentrations of $\mathrm{Cr}$ and $\mathrm{Ni}$ in the surface soils ranged between $57-334 \mathrm{mg} / \mathrm{kg}$ and $62-654 \mathrm{mg} / \mathrm{kg}$ with a median of $146 \mathrm{mg} / \mathrm{kg}$ and $206 \mathrm{mg} / \mathrm{kg}$, respectively. Subsurface soils contained $57-286 \mathrm{mg} / \mathrm{kg} \mathrm{Cr}$ (median of $157 \mathrm{mg} / \mathrm{kg}$ ) and $84-637 \mathrm{mg} / \mathrm{kg} \mathrm{Ni}$ with a median of $161 \mathrm{mg} / \mathrm{kg}$ and they did not differ significantly from those in surface soils. Chromium and $\mathrm{Ni}$ concentrations in soils from each depth interval were significantly correlated $(R=0.86$, $P<0.001$ for $0-20 \mathrm{~cm}$ soil depth and $R=0.81, P<0.01$ for $40-60 \mathrm{~cm}$ depth), indicating the same source of the metals. Compared to their mean concentrations in European soils $(21.7 \mathrm{mg} / \mathrm{kg}$ and $18.4 \mathrm{mg} / \mathrm{kg}$ for $\mathrm{Cr}$ and $\mathrm{Ni}$, respectively; [37]) and Slovak soils $(85 \mathrm{mg} / \mathrm{kg}$ and $25 \mathrm{mg} / \mathrm{kg}$ for $\mathrm{Cr}$ and $\mathrm{Ni}$, respectively; [36]), the soils of Merník are enriched with these two metals. This soil enrichment is related to the occurrence of conglomerates 
Table 1. Determined physico-chemical properties of soil samples. The mean value from the three soil samples at each sampling point is shown.

\begin{tabular}{|c|c|c|c|c|c|c|}
\hline & $\mathrm{pH}^{\mathrm{a}}$ & $\mathrm{CaCO}_{3}(\%)^{\mathrm{a}}$ & $\operatorname{TOC}(\%)^{\mathrm{a}}$ & Sand $(\%)^{\mathrm{a}}$ & Silt $(\%)^{\mathrm{a}}$ & Clay $(\%)^{\mathrm{a}}$ \\
\hline \multicolumn{7}{|c|}{ Surface soils $(0-20 \mathrm{~cm})$} \\
\hline $\mathrm{S} 1$ & 6.85 & 4.67 & 3.37 & 51.8 & 43.4 & 4.80 \\
\hline $\mathrm{S} 2$ & 6.83 & 2.75 & 3.37 & 44.9 & 40.4 & 14.7 \\
\hline $\mathrm{S} 3$ & 6.97 & 4.58 & 3.77 & 56.8 & 34.6 & 8.60 \\
\hline S4 & 7.75 & 9.67 & 1.71 & 45.2 & 47.1 & 7.70 \\
\hline S5 & 4.05 & 3.00 & 1.20 & 46.1 & 40.5 & 13.4 \\
\hline S6 & 4.02 & 4.00 & 1.87 & 39.5 & 47.0 & 13.5 \\
\hline S7 & 7.83 & 12.8 & 0.95 & 63.7 & 26.5 & 9.80 \\
\hline S8 & 7.65 & 4.85 & 1.84 & 52.5 & 36.2 & 11.3 \\
\hline S9 & 7.66 & 19.5 & 1.94 & 42.3 & 39.6 & 18.1 \\
\hline S10 & 5.22 & 3.17 & 1.21 & 20.5 & 60.9 & 18.6 \\
\hline Mean $^{\mathrm{b}}$ & 6.48 & 6.90 & 2.12 & 46.3 & 41.6 & 12.1 \\
\hline Median $^{\mathrm{b}}$ & 6.91 & 4.63 & 1.86 & 45.7 & 40.5 & 12.4 \\
\hline \multicolumn{7}{|c|}{ Subsurface soils $(40-60 \mathrm{~cm})$} \\
\hline S1 & 7.50 & 1.08 & 1.73 & 47.0 & 47.8 & 5.20 \\
\hline S2 & 7.14 & 4.58 & 3.68 & 44.6 & 42.3 & 13.1 \\
\hline S3 & 7.63 & 9.42 & 1.89 & 50.5 & 39.6 & 9.90 \\
\hline S4 & 7.52 & 12.1 & 0.83 & $\mathrm{NA}^{\mathrm{c}}$ & NA & NA \\
\hline S5 & 5.34 & 1.58 & 0.58 & 53.2 & 38.5 & 8.30 \\
\hline S6 & 6.47 & 1.58 & 0.72 & 34.6 & 52.5 & 12.9 \\
\hline S7 & 7.57 & 14.2 & 1.33 & NA & NA & NA \\
\hline S8 & 7.37 & 3.85 & 0.12 & 50.9 & 35.7 & 13.4 \\
\hline S9 & 7.71 & 8.08 & 0.83 & 38.4 & 45.4 & 16.2 \\
\hline S10 & 5.88 & 1.07 & 0.44 & 21.5 & 61.0 & 17.5 \\
\hline Mean $^{\mathrm{b}}$ & 7.01 & 5.75 & 1.22 & 42.6 & 45.4 & 12.0 \\
\hline Median $^{\mathrm{b}}$ & 7.44 & 4.22 & 0.83 & 45.8 & 43.9 & 13.0 \\
\hline
\end{tabular}

a: Arithmetic mean of three plant samples from each site. b: Arithmetic mean and median for all sampling sites. c: Not available.

with pebbles of ultrabasic rocks, enriched in $\mathrm{Cr}$ and $\mathrm{Ni}$. Hence, the soil contamination with $\mathrm{Cr}$ and $\mathrm{Ni}$ is geogenic, which was also confirmed in distant areas from this deposit [18].

The $\mu$-XRF measurements indicated that mercury was present in isolated hotspots whose major elements are $\mathrm{Hg}$ and $\mathrm{S}$ (Fig. 3). They could represent cinnabar or metacinnabar; the method is unable to distinguish the two polymorphs. The Hg-S grains are smaller than $100 \mu \mathrm{m}$. We note that in the beam diameter of $20 \mu \mathrm{m}$, very small grains could remain unnoticed. Spurious signals of elevated $\mathrm{Hg}$ concentrations were associated with some quartz grains. Spot analyses in these grains showed broad peaks centered at $10.3 \mathrm{keV}$, misinterpreted as $\mathrm{Hg}$ emission lines. They did not appear in every quartz grain and their intensity was variable even within a single quartz grain. This variability suggests that it could be a diffraction peak from quartz; the exact nature of this spectral feature was not further investigated. It is, however, unlikely that detrital quartz would harbour mercury. EXAFS spectra $\left(L_{3}\right)$ for soil and reference samples are shown in Fig. 4. However, the spectral signal of many soil samples was weak due to the low $\mathrm{Hg}$ concentration in the soil. Significant results were obtained only for some soils, where the local coordination of $\mathrm{Hg}$ could be compared to its bonding environment in cinnabar/metacinnabar. The best match is the spectrum of metacinnabar, that is, however, not too much different from that of cinnabar. Because of low Hg concentrations, the EXAFS spectra are noisy at 

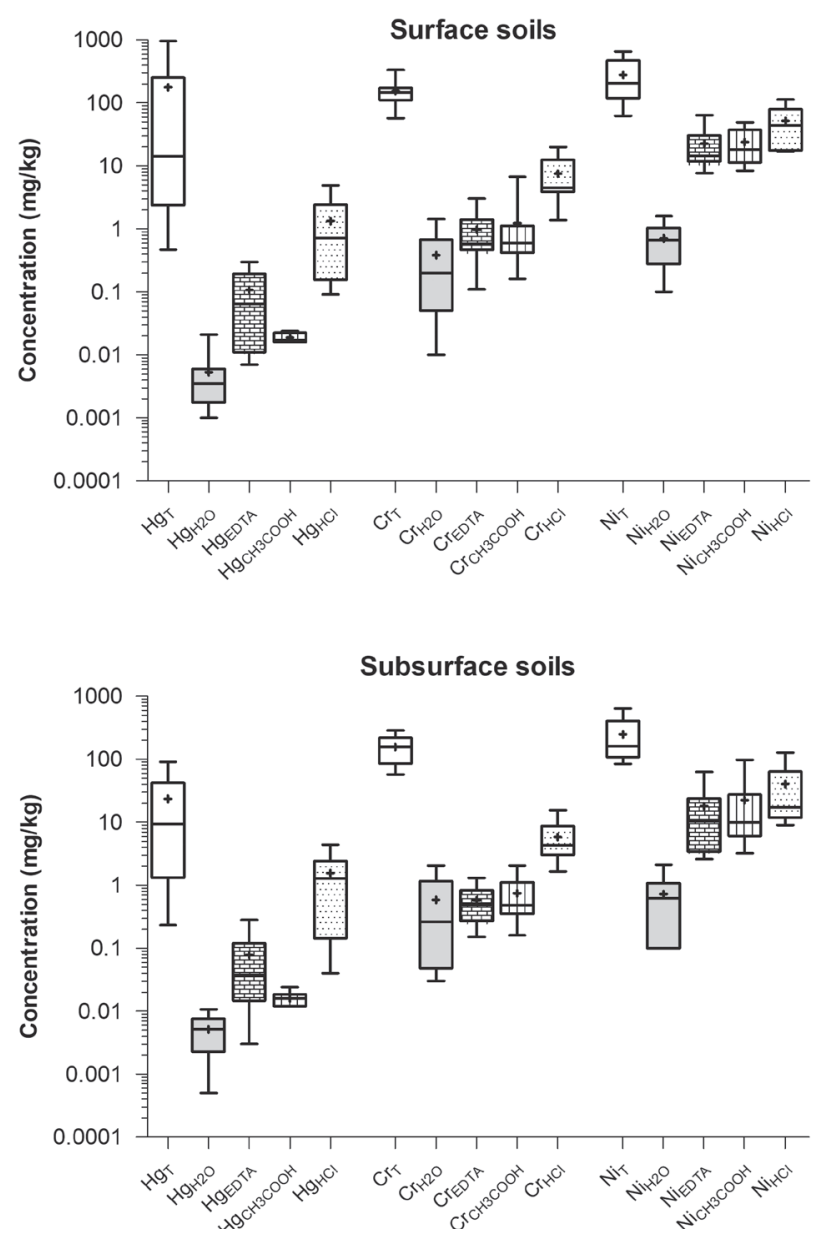

Fig. 2. Total (T) and extractable concentrations of $\mathrm{Hg}, \mathrm{Cr}$ and $\mathrm{Ni}$ using deionised water $\left(\mathrm{H}_{2} \mathrm{O}\right)$, ethylenediaminetetraacetic (EDTA), acetic $\left(\mathrm{CH}_{3} \mathrm{COOH}\right)$ and hydrochloric $(\mathrm{HCl})$ acids in mine soils from the abandoned cinnabar deposit of Merník (Eastern Slovakia). Interpretation of the boxplots is the following: the length of the box indicates the interquartile range, the horizontal line within box represents the median, the bars denote the minimum and maximum values and the crosslet is the arithmetic mean.

higher $k$ values. This noise precludes a more detailed determination if other spectral components are present, such as $\mathrm{Hg}$ adsorbed on $\mathrm{Fe}$ oxides or metallic $\mathrm{Hg}$. Nevertheless, if they should be present, they would constitute only minor $\mathrm{Hg}$ reservoir in our samples. Most of the $\mathrm{Hg}$ is stored in metacinnabar or cinnabar.

\section{Single-Step Extractions and Metal Concentrations in the Common Nettle}

The statistics of extractable concentrations of the three trace metals along with the respective total metal concentrations in soils is presented in Fig. 2 and the extractable ratio, expressed as the percentage of the total concentrations in soil that is extracted by each extraction agent, is shown in the form of boxplots (Fig. 5). Statistical comparisons among the extractable ratios of each trace metal showed that the extractability of $\mathrm{Ni}$ was significantly higher than that of $\mathrm{Hg}$ and $\mathrm{Cr}$

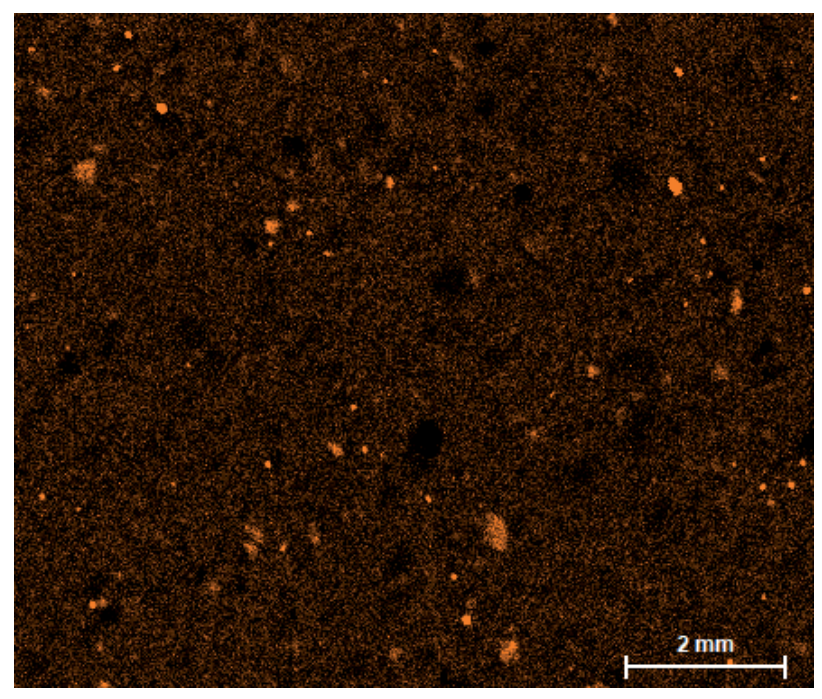

Fig. 3. Distribution of $\mathrm{Hg}$ in a thin section made of soil from Merník. Note the individual discrete spots that correlate with spots rich in sulfur. The diffuse, low-concentration anomalies are located in quartz grains and show false elevated concentrations of $\mathrm{Hg}$. For details, see text.

for all reagents, with the exception of extraction with $\mathrm{H}_{2} \mathrm{O}$ (no difference between $\mathrm{Ni}$ and $\mathrm{Cr}$ ) (Fig. 5). It can be concluded that $\mathrm{Ni}$ is a more mobile and bioavailable metal than the other two metals evaluated. When comparing the efficiencies of the individual extractants for $\mathrm{Hg}$ in soils from both sampling depths, $\mathrm{HCl}$ was found to be statistically the most effective (with a median of $5.67 \%$ ), followed by EDTA $(0.46 \%)$, with no difference in extraction efficiency between $\mathrm{H}_{2} \mathrm{O}$ and $\mathrm{CH}_{3} \mathrm{COOH}$ solution. The following order in the extraction efficiency of the individual reagents was observed for $\mathrm{Ni}: \mathrm{HCl} \geq \mathrm{CH}_{3} \mathrm{COOH} \approx \mathrm{EDTA} \gg>\mathrm{H}_{2} \mathrm{O}$, and finally for $\mathrm{Cr}$, this order: $\mathrm{HCl}>\mathrm{CH}_{3} \mathrm{COOH} \approx \mathrm{EDTA} \approx$ $\mathrm{H}_{2} \mathrm{O}$. Extractable metal concentrations were positively

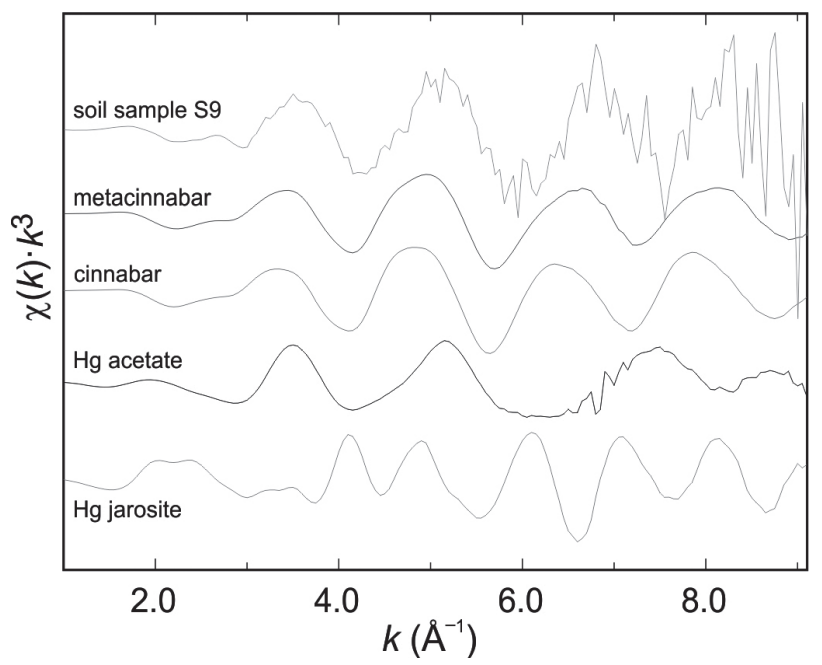

Fig. 4. EXAFS spectra of the soil sample S9 and standards, all collected at the $\mathrm{Hg} L_{3}$ edge. The spectra are vertically offset for clarity. 

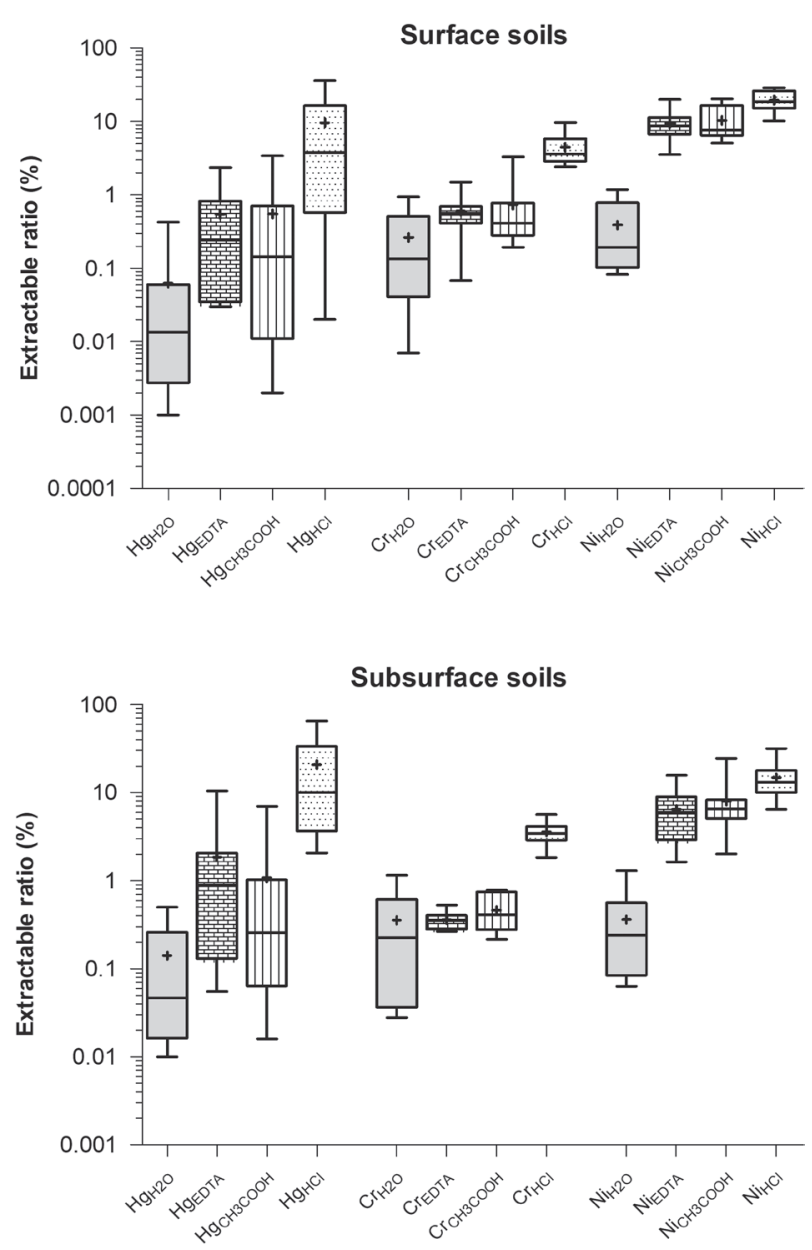

Fig. 5. Extractable ratios of $\mathrm{Hg}, \mathrm{Cr}$ and $\mathrm{Ni}$ using deionised water $\left(\mathrm{H}_{2} \mathrm{O}\right)$, ethylenediaminetetraacetic (EDTA), acetic $\left(\mathrm{CH}_{3} \mathrm{COOH}\right)$ and hydrochloric $(\mathrm{HCl})$ acids in mine soils from the abandoned cinnabar deposit of Merník (Eastern Slovakia). Interpretation of the boxplots is the following: the length of the box indicates the interquartile range, the horizontal line within box represents the median, the bars denote the minimum and maximum values and the crosslet is the arithmetic mean.

correlated with the respective total concentrations. The soil $\mathrm{pH}$ had a significant (negative) effect on the water-soluble ratios of $\mathrm{Cr}$ and $\mathrm{Ni}(R=-0.61$ and -0.64 at $P<0.01$, respectively), being much higher in soils with acidic $\mathrm{pH}$. Other soil properties did not correlate significantly with extractable ratios. Higher extractable $\mathrm{Hg}$ ratios in subsurface soils compared to those in surface soils were noted, while extractable percentage ratios of $\mathrm{Cr}$ and $\mathrm{Ni}$ did not differ significantly between surface and subsurface soils.

The concentrations of $\mathrm{Hg}, \mathrm{Cr}$ and $\mathrm{Ni}$ in the root and aboveground part of the common nettle (Urtica dioica) and the calculated values of $\mathrm{BCF}$ and $\mathrm{TF}$ are given in Table 2. There were significantly higher concentrations of $\mathrm{Hg}, \mathrm{Cr}$ and $\mathrm{Ni}$ in roots than in aboveground parts in almost all sampling stations, while TF values were below 1.0, with two exceptions. This means that nettle roots served as a biogeochemical barrier for all three elements, which is consistent with previous studies [21,
23, 25]. Mercury concentrations in the aboveground parts were always below $0.05 \mathrm{mg} / \mathrm{kg}$ and $\mathrm{BCF}$ values were quite low. The roots and aboveground parts of the common nettle had significantly higher concentrations of $\mathrm{Cr}$ and $\mathrm{Ni}$ than $\mathrm{Hg}$ ( $\mathrm{Ni}$ concentrations were also higher than $\mathrm{Cr}$ contents), while $\mathrm{BCF}$ for $\mathrm{Ni}$ was significantly higher than $\mathrm{BCF}$ for $\mathrm{Hg}$ and also higher than $\mathrm{BCF}$ for $\mathrm{Cr}$, but not significantly. The order of $\mathrm{BCF}$ indicates that $\mathrm{Ni}$ is most available to the common nettle, followed by $\mathrm{Cr}$ and finally $\mathrm{Hg}$, copying the results of in vitro extraction assays (Fig. 5). It was documented that total concentration of trace metals in soil or some soil properties could be related to plant metal concentrations $[25,29]$ but other studies found no relationships [18$19,21]$. Correlation analysis did not confirm positive relationships between $\mathrm{Hg}, \mathrm{Cr}$ and $\mathrm{Ni}$ concentrations in the roots/aboveground parts of nettle and their total concentrations in soil. More importantly, significant positive correlations between water-soluble $\mathrm{Cr} / \mathrm{Ni}$ concentrations and their concentrations in roots were observed $(R=0.699, P=0.024$ for $\mathrm{Cr}$ and $R=0.638$, $P=0.047$ for Ni). A positive correlation slightly below the significance threshold was also found between water-soluble $\mathrm{Hg}$ concentration and its concentration in roots $(R=0.599, P=0.067)$. Also, Ni concentration in the aboveground part of the common nettle and BCF values were negatively related to soil $\mathrm{pH}(R=-0.636$ and $-0.675, P=0.048$ and 0.032 , respectively). No further correlations of trace metal concentrations in plant parts with soil properties or metal concentrations leached by different reagents were documented.

\section{Discussion}

The results show that the soils are contaminated with $\mathrm{Hg}, \mathrm{Cr}$ and $\mathrm{Ni}$ due to the mining of cinnabar and the occurrence of ultrabasic-rock fragments in the conglomerates. Mercury concentrations in these mine soils do not deviate from those in soils from other mine areas with cinnabar mineralization [20, 3842]. Although the soils were shown to have increased concentrations of the three metals studied, they may not yet represent a risk to the environment because environmental hazards are mainly governed by metal mobility and availability. Therefore, the potential availability of $\mathrm{Hg}, \mathrm{Cr}$ and $\mathrm{Ni}$ in these soils as well as their actual transfer to the most widespread plant species at the site were further investigated. In general, low mobilisable $\mathrm{Hg}$ ratios were found (Fig. 5), in agreement with the spectroscopic (EXAFS) analysis that indicated that $\mathrm{Hg}$ is mostly stored in cinnabar (Fig. 4). Cinnabar possesses high resistance to chemical weathering and releases $\mathrm{Hg}$ only very slowly [4344]. Low mobilisation of $\mathrm{Hg}$ corresponds also to the findings of other studies $[22,45]$. The transfer of $\mathrm{Hg}$ to the common nettle was considerably limited, with $\mathrm{BCF}$ values well below 1.0 and $\mathrm{Hg}$ concentrations in the aboveground parts below its reference concentration 


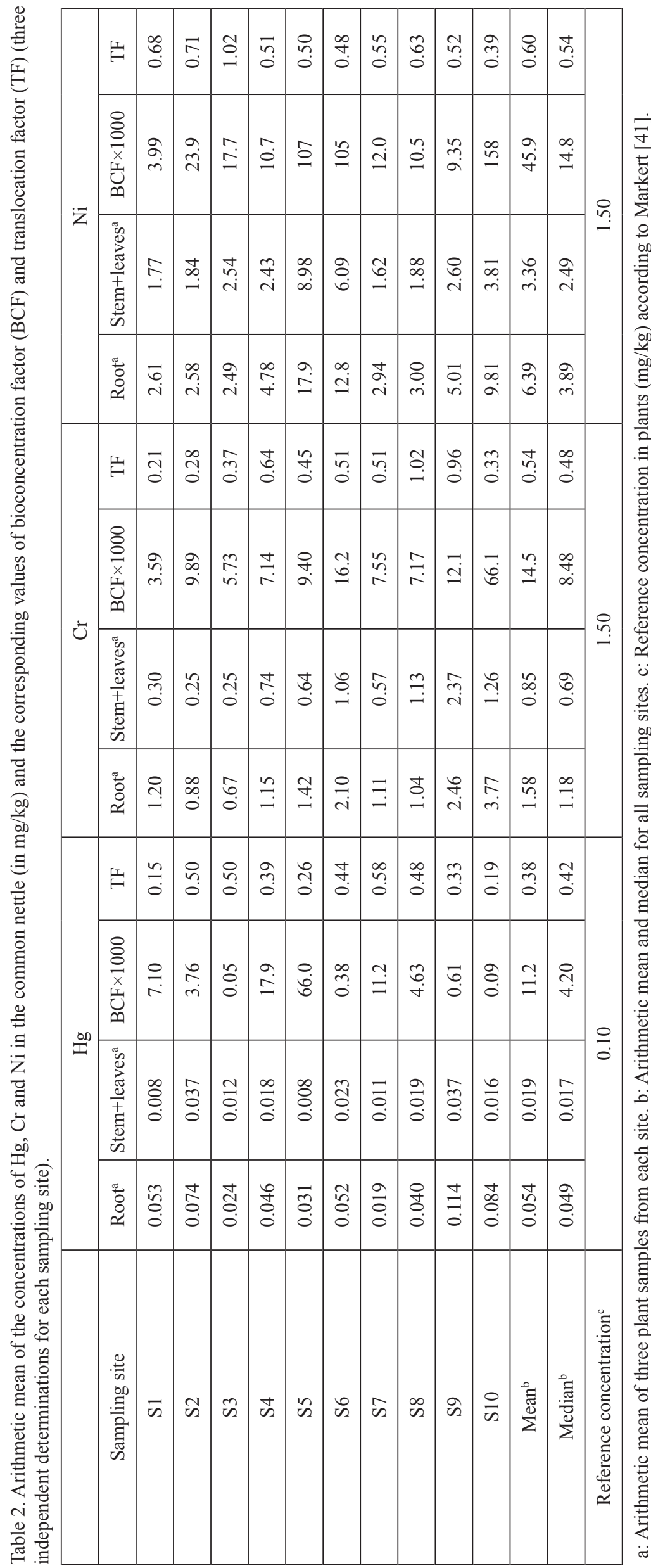


in plants [46] (Table 2). Relatively low concentrations of $\mathrm{Hg}$ in the common nettle and other vegetation species have also been reported in previous studies [23, 25, 47-49] but there are studies, suggesting significant $\mathrm{Hg}$ contamination of plants, although with low BCF values [38, 50-53]. No correlations of $\mathrm{Hg}$ concentration in roots and aboveground parts of the common nettle with its total soil content, $\mathrm{pH}, \mathrm{TOC}$, grain-size distribution and $\mathrm{Hg}$ extractable concentrations in single-step procedures (except $\mathrm{H}_{2} \mathrm{O}$ extraction) indicate the complexity of metal interaction with soils developed in heterogeneous mine environments. Significant positive relationships between $\mathrm{Hg}$ concentration in plants and its total concentration in soils or TOC were established [e.g. 47, 53-55] but in agreement with results obtained in this study, other authors also indicated no such correlations $[20,38,56]$. The results of all in vitro extractions showed higher availability of $\mathrm{Hg}$ in subsurface soils than in surface soils (Fig. 5). This fact suggests that the mobility and availability of $\mathrm{Hg}$ could be influenced by soil properties varying with depth, e.g. organic carbon content. Subsurface soils had lower TOC (Table 1) but the expected negative correlations of $\mathrm{Hg}$ extractable ratios with TOC were insignificant, however, not excluding the role of soil organic matter in the retention of $\mathrm{Hg}$ in the soils [22]. In general, the low availability of $\mathrm{Hg}$ can also be attributed to its binding to cinnabar/ metacinnabar found by EXAFS and $\mu$-XRF in surface soils with higher $\mathrm{Hg}$ concentrations. It is speculated that the presence of these two stable $\mathrm{Hg}$ sulfides in soils could control the transfer of $\mathrm{Hg}$ into the common nettle as the lowest $\mathrm{BCF}$ values were found for soils with the highest $\mathrm{Hg}$ concentration (samples S3, S6, S9 and S10) and probable occurrence of cinnabar/metacinnabar as indicated by EXAFS and $\mu$-XRF mapping. Robson [57] showed that the addition of cinnabar to the soil led to higher $\mathrm{Hg}$ concentrations in wheat and rice compared to the control soil but the BCF values were tens of times lower in the cinnabar-amended soil.

Regarding Cr, its plant uptake and potential mobility and availability were higher compared to $\mathrm{Hg}$ but still very low. Moreover, the common nettle was not able to translocate $\mathrm{Cr}$ from roots to aboveground parts (TF values $<0.1)$. Despite its low availability, $\mathrm{Cr}$ was present in the aboveground parts of the plant in concentrations that exceeded the respective reference concentration in plants according to [46] (Table 2). Several studies evaluated the transfer of soil $\mathrm{Cr}$ to plants and also recorded its minimal migration with $\mathrm{BCF}$ values below $0.1[13,21,23]$. From the point of view of geochemical fractionation, $\mathrm{Cr}$ in soils occurs mainly in residual pools that are generally stable and not available [11]. Although no attention has been paid here to the mineralogy of chromium in soils, Soták et al. [58] confirmed that $\mathrm{Cr}$ occurs in conglomerates in the form of Cr-bearing spinels, i.e. in minerals that are resistant to weathering [59-60]. This also explains the lack of correlations between $\mathrm{Cr}$ concentration in the common nettle and the soil physico-chemical properties/total $\mathrm{Cr}$ concentration in soil. Only a significant correlation of total $\mathrm{Cr}$ concentration in roots with water-extractable $\mathrm{Cr}$ concentration was found, which may suggest that the most readily available $\mathrm{Cr}$ is preferentially accumulated from the soil.

Nickel was the most mobile and available among the studied metals. The median $\mathrm{BCF}$ value for $\mathrm{Ni}$ was 2-3 times higher than the BCF values of $\mathrm{Hg}$ and $\mathrm{Cr}$ (Table 2) and the concentration of $\mathrm{Ni}$ in the common nettle exceeded the respective background concentration in plants $(1.5 \mathrm{mg} / \mathrm{kg})$ at all sampling sites. The obtained results agree with the study of Čurlík et al. [18] who examined the concentrations of $\mathrm{Cr}$ and $\mathrm{Ni}$ in plants (common dandelion - Taraxacum officinale and common agrimony - Agrimonia eupatoria) and confirmed the geogenic contamination of plants growing on soils derived from rocks of the Central Carpathian Paleogene, i.e. in the area geologically similar to that investigated in this study. These authors and others [13, 18, 21, 61-62] also pointed to the higher plant availability of $\mathrm{Ni}$ than $\mathrm{Cr}$ regardless of different geological and soil conditions. The highest availability of $\mathrm{Ni}$ to the common nettle among the studied metals agreed with its highest ratios extractable by EDTA and $\mathrm{CH}_{3} \mathrm{COOH}$ solutions, which release $\mathrm{Ni}$ from exchangeable positions, bound in carbonates and organic matter [27-28]. Detailed mineralogical studies of mineralization in the ultrabasic rock pebbles in conglomerates showed that $\mathrm{Ni}$ occurs here as awaruite and millerite accompanied by supergene Ni-rich vermiculite [31]. Nickel in vermiculite was shown to be located in the interlayer space and the octahedral layer of intercalated vermiculite [63], meaning that Ni could be easily released at least from the interlayer space of vermiculite where it is in exchangeable form. Nickel was also not translocated to the aboveground parts of the common nettle $(\mathrm{TF}<1.0$, Table 2$)$ but it accumulated predominantly in the roots. Nickel sequestration proceeds in the cation exchange sites of the walls of xylem parenchyma cells and immobilization in the vacuoles of the roots [64], the latter mechanisms responsible also for $\mathrm{Cr}$ accumulation in plant roots [65]. Bioconcentration factor and water-soluble ratios of $\mathrm{Ni}$ were sensitive to soil $\mathrm{pH}$, with higher values in more acid soils, which indicated higher $\mathrm{Ni}$ availability from acid soils. An identical finding was described by [18] for Ni uptake by the common dandelion and agrimony. $\mathrm{pH}$-dependent $\mathrm{Ni}$ availability is due to the fact that its adsorption and leaching behaviour in soils depend strongly on the soil $\mathrm{pH}$ with a significant increase of $\mathrm{Ni}$ solubility at $\mathrm{pH}$ less than $6.5[60,66]$.

This study reveals that the soils in the abandoned mine area of Merník are contaminated with $\mathrm{Hg}$ due to historical cinnabar mining. The specific geology of the mine area also led to geogenic contamination of soils with other trace metals, mostly $\mathrm{Cr}$ and $\mathrm{Ni}$ (details can be found in an accompanying study of Kulikova et al. [30]). This hints that there would be a risk to the environment resulting from soil contamination. 
However, the results of in vitro single-step extractions of the soils and bioavailability study with the common nettle showed that mobile and available ratios of the three trace metals were low. This finally agreed well with previous studies in the mine area, which showed that $\mathrm{Hg}$ concentrations in tree leaves were negligible [67] as well as $\mathrm{Hg}$ and $\mathrm{Cr}$ concentrations in surface and groundwater were low, not exceeding their respective limit values [67-68]. Only the concentrations of $\mathrm{Ni}$ in some water samples were increased, which is probably related to its higher leachability found in single-step extractions. Bottom sediments were shown to be enriched in $\mathrm{Hg}$ and $\mathrm{Ni}$, suggesting that they serve as a significant sink for these trace metals [67-68], possibly via sulfidation. Other works from Slovak mine areas with similar $\mathrm{Hg}$ mineralization also showed considerable contamination of soils and sediments with $\mathrm{Hg}$ but no significant impact on biota and surface water quality in terms of concentrations of this toxic metal [20,41, 69-71]. In addition, soil contamination is present only within the former mine area, while $\mathrm{Hg}$ concentrations in soils outside the mine area do not exceed the background concentration of $0.08 \mathrm{mg} / \mathrm{kg}$ [36]. Therefore, the mine area does not pose any contamination risk to the environment outside it. One of the explanations is that in the mine area of Merník, $\mathrm{Hg}$ in soils occurs mostly as cinnabar/metacinnabar. These sulfide minerals have considerable stability towards the chemical weathering in supergene conditions [43-44]. As a result, mobile and plant available ratios of $\mathrm{Hg}$ are low and the greatest part of the metal is accumulated in soils and aquatic sediments. From that reason, natural waters typically contain low $\mathrm{Hg}$ concentrations [43, 45].

\section{Conclusions}

This study aimed to evaluate the potential mobility and environmental availability of three trace metals - $\mathrm{Hg}, \mathrm{Cr}$ and $\mathrm{Ni}$ - in highly disturbed mine soils of the abandoned cinnabar deposit of Merník (Eastern Slovakia). The surface soils of the former mine area are enriched in all three metals (median of $14.2 \mathrm{mg}$ / $\mathrm{kg}, 146 \mathrm{mg} / \mathrm{kg}$ and $206 \mathrm{mg} / \mathrm{kg}$ for $\mathrm{Hg}, \mathrm{Cr}$ and $\mathrm{Ni}$, respectively), with soil contamination related to the $\mathrm{Cr}$ and Ni-enriched bedrock and mining and roasting of $\mathrm{Hg}$ ores (mainly cinnabar) in the case of $\mathrm{Hg}$. However, the high total concentrations of trace metals in soils do not mean that the area is hazardous in relation to other components of the environment, such as water, plants and humans. According to in vitro single-step extractions with four chemical agents of different reactivity and selectivity (deionised $\mathrm{H}_{2} \mathrm{O}, \mathrm{CH}_{3} \mathrm{COOH}$, EDTA and $\mathrm{HCl}$ ) and the plant uptake study with the common nettle (Urtica dioica), $\mathrm{Hg}$ and $\mathrm{Cr}$ are immobile in soils and their uptake by the common nettle is low, with plant root:soil ratios not exceeding 0.20 and even lower plant aerial part:soil ratios. Complementary experimental work with selected soil samples using $\mu$-XRF and EXAFS techniques, and existing data on the mineralogy of underlying sedimentary formations show that host $\mathrm{Hg}$ phases in soils are stable $\mathrm{Hg}$ sulfides (cinnabar/metacinnabar) under supergene conditions and $\mathrm{Cr}$ is bound to insoluble spinels. This explains the negligible mobility and plant uptake of the two metals in the mine soils of the Merník deposit. Nickel released from soils only in low concentrations and its uptake by Urtica dioica was not very significant but compared to $\mathrm{Hg}$ and $\mathrm{Cr}$, it had significantly higher availability, which correlated with soil $\mathrm{pH}$. The explanation can be found in the fact that $\mathrm{Ni}$ is present in more unstable pools, i.e. exchangeable form and carbonates as indicated by its higher ratios in $0.43 \mathrm{M} \mathrm{CH}_{3} \mathrm{COOH}$ and $0.05 \mathrm{M}$ EDTA solutions and sulfides (millerite), alloys (awaruite) and $\mathrm{Ni}$-vermiculite in the pebbles of ultrabasic rocks, which are part of the country rocks of the deposit.

\section{Acknowledgements}

We thank the projects VEGA No. 1/0597/17 and APVV No. APVV-17-0317 for financial support. We acknowledge the KARA (Karlsruhe Research Accelerator) for the provision of the beamtime at the SUL-X beamline and the help of Jörg Göttlicher and Ralph Steininger during the collection of the data. We would like to thank two anonymous reviewers for their positive response to this manuscript.

\section{Conflict of Interest}

The authors declare no conflict of interest.

\section{References}

1. GASCHNIG R.M., RUDNICK R.L., MCDONOUGH W.F., KAUFMAN A.J., VALLEY J.W., HU Z., GAO S., BECK M.L. Compositional evolution of the upper continental crust through time, as constrained by ancient glacial diamictites. Geochimica et Cosmochimica Acta, 186, 316, 2016.

2. WEDEPOHL K.H. The composition of the continental crust. Geochimica et Cosmochimica Acta, 59 (7), 1217, 1995.

3. SHAHID N.M., KHALID S., BIBI I., BUNDSCHUH J., NIAZI N.K., DUMAT C. A critical review of mercury speciation, bioavailability, toxicity and detoxification in soil-plant environment: Ecotoxicology and health risk assessment. Science of The Total Environment, 711, 134749, 2020.

4. DRISCOLL C.T., MASON R.P., CHAN H.M., JACOB D.J., PIRRONE N. Mercury as a global pollutant: Sources, pathways, and effects. Environmental Science \& Technology, 47 (10), 4967, 2013.

5. RAHMAN Z., SINGH V.P. The relative impact of toxic heavy metals (THMs) (arsenic (As), cadmium $\mathrm{Cd}$ ), chromium $(\mathrm{Cr})(\mathrm{VI})$, mercury $(\mathrm{Hg})$, and lead $(\mathrm{Pb}))$ on 
the total environment: an overview. Environmental Monitoring and Assessment, 191 (7), 419, 2019.

6. MAHBUB K.R., KRISHNAN K., NAIDU R., ANDREWS S., MEGHARAJ M. Mercury toxicity to terrestrial biota. Ecological Indicators, 74, 451, 2017.

7. KWIATKOWSKA-MALINA J., BORKOWSKI A.S.Geostatistical modelling of soil contamination with arsenic, cadmium, lead, and nickel: the Silesian voivodeship, Poland case study. AIMS Geosciences, 6 (2), 135, 2020.

8. MICEVSKA O., HRISTOVSKI S., MELOVSKI L. The impact of the ferro-nickel smelter's fugitive dust emission on heavy metal content in soils and whitetop (Lepidium draba L.) in Kavadarci, Republic of Macedonia. Fresenius Environmental Bulletin, 28 (2A), 1189, 2019.

9. ERTANI A., MIETTO A., BORIN M., NARDI S. Chromium in agricultural soils and crops: a review. Water, Air, and Soil Pollution, 228 (1-4), 190, 2017.

10. SOLGI E., PARMAH J. Analysis and assessment of nickel and chromium pollution in soils around Baghejar chromite mine of Sabzevar ophiolite belt, northeastern Iran. Transactions of Nonferrous Metals Society of China, 25 (7), 2380, 2015.

11. GONNELLI C., RENELLA G. Chromium and nickel. In ALLOWAY B. (Ed.) Heavy metals in soils. Environmental Pollution, vol. 22. Springer, Dordrecht, 313, 2013.

12. HSEU Z.Y., LAI Y.J. Nickel accumulation in paddy rice on serpentine soils containing high geogenic nickel contents in Taiwan. Environmental Geochemistry and Health, 39 (6), 1325, 2017.

13. SAGLAM C. Heavy metal concentrations in serpentine soils and plants from Kizildag national park (Isparta) in Turkey. Fresenius Environmental Bulletin, 26 (6), 3995, 2017.

14. STAJKOVIĆ-SRBINOVIĆ O., DELIĆ D., RASULIĆ N., KUZMANOVIĆ D., HOUŠKOVÁ B., SIKIRIĆ B., MRVIĆ V. Microorganisms in soils with high nickel and chromium concentrations in Western Serbia. Polish Journal of Environmental Studies, 26 (4), 1663, 2017.

15. CHRYSOCHOOU M., THEOLOGOU E., BOMPOTI N., DERMATAS D., PANAGIOTAKIS I. Occurrence, origin and transformation processes of geogenic chromium in soils and sediments. Current Pollution Reports, 2 (4), 224, 2016.

16. PĘDZIWIATR A., KIERCZAK J., POTYSZ A., TYSZKA R., SŁODCZYK E. Interactive effects of $\mathrm{Ni}, \mathrm{Cr}, \mathrm{Co}, \mathrm{Ca}$, and $\mathrm{Mg}$ in seeds germination test: Implications for plant growth in ultramafic soils. Polish Journal of Environmental Studies, 29 (5), 3235, 2020.

17. WANG Y.L., TSOU M.C., LIAO H.T., HSEU Z.Y., DANG W., HSI H.C., CHIEN L.C. Influence of soil properties on the bioaccessibility of $\mathrm{Cr}$ and $\mathrm{Ni}$ in geologic serpentine and anthropogenically contaminated non-serpentine soils in Taiwan. Science of The Total Environment, 714, 136761, 2020.

18. ČURLÍK J., KOLESÁR M., ĎURŽA O., HILLER E. Dandelion (Taraxacum officinale) and agrimony (Agrimonia eupatoria) as indicators of geogenic contamination of flysch soils in Eastern Slovakia. Archives of Environmental Contamination and Toxicology, 70 (3), 475, 2016.

19. HAN Z., WAN D., TIAN H., HE W., WANG Z., LIU Q. Pollution assessment of heavy metals in soils and plants around a molybdenum mine in Central China. Polish Journal of Environmental Studies, 28 (1), 123, 2019.
20. ÁRVAY J., DEMKOVÁ L., HAUPTVOGL M., MICHALKO M., BAJČAN D., STANOVIČ R., TOMÁŠ J., HRSTKOVÁ M., TREBICHALSKÝ P. Assessment of environmental and health risks in former polymetallic ore mining and smelting area, Slovakia: Spatial distribution and accumulation of mercury in four different ecosystems. Ecotoxicology and Environmental Safety, 144, 236, 2017.

21. KUKLOVÁ M., KUKLA J., GAŠOVÁ K. Chromium and nickel accumulation by plants along an altitudinal gradient in Western Carpathian secondary spruce stands. Polish Journal of Environmental Studies, 25 (4), 1563, 2016.

22. RÓŻAŃSKI S.Ł., CASTEJÓN J.M.P., FERNÁNDEZ G.G. Bioavailability and mobility of mercury in selected soil profiles. Environmental Earth Sciences, 75 (13), 1065, 2016.

23. BALABANOVA B., STAFILOV T., BAČEVA K. Bioavailability and bioaccumulation characterization of essential and heavy metals contents in $R$. acetosa, $S$. oleracea and $U$. dioica from copper polluted and referent areas. Journal of Environmental Health Science \& Engineering, 13 (2), 13, 2015.

24. KANELLOPOULOS C., ARGYRAKI A., MITROPOULOS P. Geochemistry of serpentine agricultural soil and associated groundwater chemistry and vegetation in the area of Atalanti, Greece. Journal of Geochemical Exploration, 158, 22, 2015.

25. EDWARDS S.C., MACLEOD C.L., LESTER J.N. The bioavailability of copper and mercury to the common nettle (Urtica dioica) and the earthworm Eisenia fetida from contaminated dredge spoil. Water, Air, and Soil Pollution, 102 (1-4), 75, 1998.

26. TACK F.M., VERLOO M.G. Metal contents in stinging nettle (Urtica dioica L.) as affected by soil characteristics. Science of The Total Environment, 192 (1), 31, 1996.

27. SAHUQUILLO A., RIGOL A., RAURET G. Overview of the use of leaching/extraction tests for risk assessment of trace metals in contaminated soils and sediments. Trends in Analytical Chemistry, 22 (3), 152, 2003.

28. GARCÍA-SALGADO S., ÁNGELES QUIJANO M. Rapid metal extractability tests from polluted mining soils by ultrasound probe sonication and microwave-assisted extraction systems. Environmental Science and Pollution Research, 23 (24), 24567, 2016.

29. CAO X., WANG X., TONG W., GURAJALA H.K., LU M., HAMID Y., FENG Y., HE Z., YANG X. Distribution, availability and translocation of heavy metals in soiloilseed rape (Brassica napus L.) system related to soil properties. Environmental Pollution, 252 Part A, 733, 2019.

30. KULIKOVA T., HILLER E., JURKOVIČ L', FILOVÁ L., ŠOTTNÍK P., LACINA P. Total mercury, chromium, nickel and other trace chemical element contents in soils at an old cinnabar mine site (Merník, Slovakia): anthropogenic versus natural sources of soil contamination. Environmental Monitoring and Assessment, 191 (5), 263, 2019.

31. ĎUĎA R., KALIČIAKOVÁ E. Mineralogical-paragenetic conditions in the Merník Hg deposit. Mineralia Slovaca, 19 (5), 423, 1987 [In Slovak with English abstract and summary].

32. PENG Y., KEATING K., MYERS D.B. NMR relaxation times for soil texture estimation in the laboratory: A comparison to the laser diffraction and sieve-pipette methods. European Journal of Soil Science, https://doi. org/10.1111/ejss.13030, 2020. 
33. ROJE V., GALINEC F. Water as a mild extractant of metals and metalloids from the samples of the selected certified reference materials and subsequent multielemental quantification by ICP-AES. Environmental Monitoring and Assessment, 191 (9), 534, 2019.

34. GROENENBERG J.E., RÖMKENS P.F.A.M., VAN ZOMEREN A., RODRIGUES S.M., COMAS R.N.J. Evaluation of the single dilute $(0.43 \mathrm{M})$ nitric acid extraction to determine geochemically reactive elemnets in soil. Environmental Science \& Technology, 51 (4), 2246, 2017.

35. RIVERA M.B., GIRÁLDEZ M.I., FERNÁNDEZCALIANI J.C. Assessing the environmental availability of heavy metals in geogenically contaminated soils of the Sierra de Aracena Natural Park (SW Spain). Is there a health risk?. Science of The Total Environment, 560-561, 254, 2016.

36. ČURLÍK J., ŠEFČÍK P. Geochemical Atlas of the Slovak Republic. Part V - Soils, 1st ed.; Soil Science and Conservation Research Institute: Bratislava, the Slovak Republic, 1999.

37. TÓTH G., HERMANN T., SZATMÁRI G., PÁSZTOR L. Maps of heavy metals in the soils of the European Union and proposed priority areas for detailed assessment. Science of The Total Environment, 565, 1054, 2016.

38. CAMPOS J.A., ESBRÍ J.M., MADRID M.M., NAHARRO R., PECO J., GARCÍA-NOGUERO E.M., AMORÓS J.A., MORENO M.M., HIGUERAS P. Does mercury presence in soils promote their microbial activity? The Almadenejos case (Almadén mercury mining district, Spain). Chemosphere, 201, 799, 2018

39. TOMIYASU T., KODAMATANI H., IMURA R., MATSUYAMA A., MIYAMOTO J., AKAGI H., KOCMAN D., KOTNIK J., FAJON V., HORVAT M. The dynamics of mercury near Idrija mercury mine, Slovenia: horizontal and vertical distributions of total, methyl, and ethyl mercury concentrations in soils. Chemosphere, 184, 244, 2017.

40. CAMACHO A., VAN BRUSSEL E., CARRIZALES L., FLORES-RAMÍREZ R., VERDUYCO B., HUERTA S.R., LEÓN M., DÍAZ-BARRIGA F. Mercury mining in Mexico: I. Community engagement to improve health outcomes from artisanal mining. Annals of Global Health, 82 (1), 149, 2016.

41. DADOVÁ J., ANDRÁŠ P., KUPKA J., KRNÁČ J., ANDRÁŠ JR.P., HRONCOVÁ E., MIDULA P. Mercury contamination from historical mining territory at Malachov Hg-deposit (Central Slovakia). Environmental Science and Pollution Research, 23 (3), 2914, 2016.

42. BAVEC Š., GOSAR M., BIESTER H., GRČMAN H. Geochemical investigation of mercury and other elements in urban soil of Idrija (Slovenia). Journal of Geochemical Exploration, 154, 213, 2015.

43. QUINTANILLA-VILLANUEVA G.E., VILLANUEVARODRÍGUEZ M., GUZMÁN-MAR J.L., TORRESGAYTAN D.E., HERNÁNDEZ-RAMÍREZ A., OROZCO-RIVERA G., HINOJOSA-REYES L. Mobility and speciation of mercury in soils from a mining zone in Villa Hidalgo, SLP, Mexico: a preliminary risk assessment. Applied Geochemistry, 122, 104746, 2020.

44. FERNÁNDEZ-MARTÍNEZ R., ESBRÍ J.M., HIGUERAS P., RUCANDIO I. Comparison of mercury distribution and mobility in soils affected by anthropogenic pollution around chloralkali plants and ancient mining sites. Science of The Total Environment, 671, 1066, 2019.
45. MORTON-BERMEA O., JIMÉNEZ-GALICIA R.G., CASTRO-LARRAGOITIA J., HERNÁNDEZ-ÁLVAREZ E., PÉREZ-RODRÍGUEZ R., GARCÍA-ARREOLA M.E., GAVILÁN-GARCÍA I., SEGOVIA N. Anthropogenic impact of the use of $\mathrm{Hg}$ in mining activities in Cedral S.L.P. Mexico. Environmental Earth Sciences, 74 (2), 1161, 2015.

46. MARKERT B. Presence and significance of naturally occurring chemical elements of the periodic system in the plant organism and consequences for future investigations on inorganic environmental chemistry in ecosystems. Vegetatio, 103 (1), 1, 1992.

47. LI Q., TANG L., QIU G., LIU C. Total mercury and methylmercury in the soil and vegetation of a riparian zone along a mercury-impacted reservoir. Science of The Total Environment, 738, 139794, 2020.

48. HLODÁK M., MATÚŠ P., URÍK M., KOŘENKOVÁ L., MIKUŠOVÁ P., SENILA M., DIVIŠ P. Evaluation of various inorganic and biological extraction techniques suitability for soil mercury phytoavailable fraction assessment. Water, Air, and Soil Pollution, 226 (1-4), 198, 2015.

49. ROCIO M., ELVIRA E., PILAR Z., MARÍA-JOSÉ S. Could an abandoned mercury mine area be cropped? Environmental Research, 125, 150, 2013.

50. KIMÁKOVÁ T., VARGOVÁ V., ONAČILLOVÁ E., CIMBOLÁKOVÁ I., UHER I., HARICH P., SCHUSTER J., PORÁČOVÁ J. Mercury accumulation in plants from contaminated arable lands in Eastern Slovakia. Annals of Agricultural and Environmental Medicine, 27 (1), 29, 2020.

51. ALI AS M, AHMED HA M, EMARA HA E, JANJUA MN, ALHAFEZ N. Estimation and bio-availability of toxic metals between soils and plants. Polish Journal of Environmental Studies, 28 (1), 15, 2019.

52. QIAN X., WU Y., ZHOU H., XU X., XU Z., SHANG L., QIU G. Total mercury and methylmercury accumulation in wild plants grown at wastelands composed of mine tailings: Insights into potential candidates for phytoremediation. Environmental Pollution, 239, 757, 2018.

53. HIGUERAS P.L., AMORÓS J.Á., ESBRÍ J.M., PÉREZDE-LOS-REYES C., LÓPEZ-BERDONCES M.A., GARCÍA-NAVARRO F.J. Mercury transfer from soil to olive trees. A comparison of three different contaminated sites. Environmental Science and Pollution Research, 23 (7), 6055, 2016.

54. ZHANG Q., WANG S., NAN Z., LI Y., ZANG F. Accumulation, fractionation, and risk assessment of mercury and arsenic in the soil-wheat system from the wastewater-irrigated soil in Baiyin, northwest China. Environmental Science and Pollution Research, 25 (15), 14856, 2018.

55. GU Q., YU T., YANG Z., JI J., HOU Q., WANG L., WEI $\mathrm{X}$., ZHANG Q. Prediction and risk assessment of five heavy metals in maize and peanut: a case study of Guangxi, China. Environmental Toxicology and Pharmacology, 70, 103199, 2019.

56. WAHSHA M., MALECI L., BINI C. The impact of former mining activity on soils and plants in the vicinity of an old mercury mine (Vallalta, Belluno, NE Italy). Geochemistry: Exploration, Environment, Analysis, 19 (2), 171, 2019

57. ROBSON T.C. Weathering of sulfide ores in model soils, potentially toxic element release and bioavailability. Dissertation thesis, University of Plymouth, 2013. 
58. SOTÁK J., KRIŽÁNI I., SPIŠIAK J. On position and material composition of the Merník conglomerates (the Central Carpathian Paleogene). Acta Geologica et Geographica Universitatis Comenianae, Geologica, 45, 117, 1990.

59. LILLI M.A., NIKOLAIDIS P.N., KARATZAS P., KALOGERAKIS N. Identifying the controlling mechanisms of geogenic origin chromium release in soils. Journal of Hazardous Materials, 366, 169, 2019.

60. QUANTIN C., ETTLER V., GARNIER J., ŠEBEK O. Sources and extractibility of chromium and nickel in soil profiles developed on Czech serpentinites. Comptes Rendus Geoscience, 340 (12), 872, 2008.

61. LAGO-VILA M., ARENAS-LAGO D., RODRÍGUEZSEIJO A., ANDRADE COUCE M.L., VEGA F.A. Cobalt, chromium and nickel contents in soils and plants from a serpentinite quarry. Solid Earth, 6, 323, 2015.

62. KACÁLKOVÁ L., TLUSTOŠ P., SZÁKOVÁ J. Chromium, nickel, cadmium, and lead accumulation in maize, sunflower, willow, and poplar. Polish Journal of Environmental Studies, 23 (3), 753, 2014.

63. PASCUAL C.M., ARGÜELLES A., LEONI M., KHAINAKOV S.A., BLANCO J.A. Location of $\mathrm{Ni}^{2+}$ in nickel-intercalated vermiculites. Applied Clay Science, 91-92, 79, 2014.

64. AMEEN N., AMJAD M., MURTAZA B., ABBAS G., SHADID M., IMRAN M., NAEEM M.A., NIAZI N.K. Biogeochemical behavior of nickel under different abiotic stresses: toxicity and detoxification mechanisms in plants. Environmental Science and Pollution Research, 26 (11), 10496, 2019.
65. SHARMA A., KAPOOR D., WANG J., SHAHZAD B., KUMAR V., BALI A.S., JASROTIA S., ZHENG B., YUAN H., YAN D. Chromium bioaccumulation and its impacts on plants: an overview. Plants, 9 (1), 100, 2020.

66. ELBANA T.A., SELIM H.M., AKRAMI N., NEWMAN A., SHAHEEN S.M., RINKLEBE J. Freundlich sorption parameters for cadmium, copper, nickel, lead, and zinc for different soils: Influence of kinetics. Geoderma, 324, 80, 2018.

67. HANČULÁK J., BOBRO M., ŠESTINOVÁ O., BREHUV J., SLANČO P. Mercury in the surrounding of old mining loads of Rudňany and Merník. Acta Montanistica Slovaca, 11 (2), 295, 2006 [In Slovak with English abstract].

68. JURKOVIČ L., ŠOTTNÍK P., SEKULA P., PEŤKOVÁ K., KOTÚČ J., LEŠŠO J., BAČIK M., HILLER E., MALÝ V. Geochemical evaluation of environmental risks in locality of abandoned Hg-deposit Merník (Eastern Slovakia). Mineralia Slovaca, 48 (2), 157, 2016 [In Slovak with English abstract and summary].

69. HLODÁK M., MATÚŠ P., URÍK M., KOŘENKOVÁ L., MIKUŠOVÁ P. Biogeochemistry of Hg in soil-plant system in anthropogenically contaminated area. Chemické Listy, 109 (5), 385, 2015 [In Slovak with English summary].

70. ANGELOVIČOVÁ L., FAZEKAŠOVÁ D. Contamination of the soil and water environment by heavy metals in the former mining area of Rudňany (Slovakia). Soil and Water Research, 9 (1), 18, 2014.

71. MAŇKOVSKÁ B. Mercury concentrations in forest trees from Slovakia. Water, Air, and Soil Pollution, 89 (1-4), 267, 1996. 